\title{
EFFECTS OF LOW MOLECULAR WEIGHT ORGANIC ANIONS ON THE RELEASE OF ARSENITE AND ARSENATE FROM A CONTAMINATED SOIL
}

\author{
SHUZHEN ZHANG ${ }^{1, *}$, WEI LI ${ }^{1}$, XIAO-QUAN SHAN ${ }^{1}$, ANXIANG LU $^{1}$ \\ and PEIJIANG ZHOU ${ }^{2}$ \\ ${ }^{1}$ State Key Laboratory of Environmental Chemistry and Ecotoxicology, Research Center for \\ Eco-Environmental Sciences, Chinese Academy of Sciences, P.O. Box 2871, 100085, China; \\ ${ }^{2}$ Department of Environmental Science, Wuhan University, Wuhan 430072, China \\ (*author for correspondence, e-mail: szzhang@mail.rcees.ac.cn, Tel.: +86-10-62849683; \\ Fax: +86-10-62923563)
}

(Received 24 March 2005; accepted 31 May 2005)

\begin{abstract}
Low-molecular-weight-organic-anions (LMWOAs) are important exudates of plants and may influence the mobility and bioavailability of metals or metalloids. In the present study the effects of selected LMWOAs, citrate, malate and oxalate, on the release of arsenite (As(III)) and arsenate $(\mathrm{As}(\mathrm{V}))$ in a contaminated soil were investigated. The organic anions have significant influence upon the release of arsenic from the soil, and a linear relationship exits between the released arsenic and the concentration of LMWOAs in the extractants. $\mathrm{pH}$ effects on the arsenite and arsenate adsorption were not significant over the range from 3 to 7 . The amounts of arsenite and arsenate released were significantly correlated with the release of $\mathrm{Fe}, \mathrm{Mn}$ and $\mathrm{Al}$, suggesting that arsenic was mainly released from $\mathrm{Fe}-, \mathrm{Mn}$ - and $\mathrm{Al}$-oxides or hydroxides in soil. The ratio of released arsenite to arsenate was not influenced by LMWOAs.
\end{abstract}

Keywords: arsenite, arsenate, low-molecular-weight-organic-anions, release, soil

\section{Introduction}

Arsenic is ubiquitous in soils with the concentrations ranging from 1 to $40 \mathrm{mg} / \mathrm{kg}$ in uncontaminated soils. However, much higher concentration of arsenic is present in a very large number of places in the world (Mandal and Suzuki, 2002). Drinking of As-contaminated groundwater is perhaps the most common exposure pathway of humans to arsenic (Berg et al., 2001). As a consequence more stringent limits for arsenic in drinking water have been recently proposed (European Union, 1998; Christen, 2000). Arsenic contamination in soil may be prevalent at mining and industrial sites (Brandestetter et al., 2000). Leaching of arsenic from the contaminated soils could pose a potential risk to groundwater quality, as well as the mobility and bioavailability of arsenic in soil-water-plant systems (Barrow, 1974; Livesey and Huang, 1981). Therefore, it is necessary to investigate the potential mobilization of arsenic in soils, especially in the contaminated soils. 
Mobilization of arsenic in soil has been intensively investigated and it is mainly affected by the soil biogeochemical factors, such as soil texture, organic matter, nature and constituents of minerals, $\mathrm{pH}$, redox potential, competing ions (Adriano, 2001). Although arsenic has a high affinity to soil, when the environmental condition changes, the mobility and even speciation of arsenic may be changed. For instance, in natural ecosystems the rhizosphere processes always occur and lead to the exudation of some organic anion into soil. Such processes may have an impact on the mobilization of arsenic in soil and lead to the release of arsenic into ground and surface water. Therefore, it is important to have a better understanding of the effects of organic anions upon the mobility of arsenic. Generally, only the mobile fraction of toxic metals in the soil is easily available by plants. Such mobilization must also be taken into account when arsenic phyto-accumulation is assessed.

In the rhizosphere, plant roots can exude many organic compounds; among them low-molecular-weight-organic-anions (LMWOAs) are important. Through the effect of acidification, chelation and oxidation-reduction reactions in the rhizosphere, LMWOAs can influence metal solubility in soils and uptake by plants. Cieslinski et al. (1998) found that LMWOAs in rhizosphere soils could influence the solubilization of particulate-bound cadmium in soil solutions; Jones et al. (1994) indicated that organic acids mediated iron dissolution in the rhizosphere. Although the importance of arsenic pollution in soils is widely recognized, virtually little is known about the effect of LMWOAs in rhizosphere processes upon the mobilization of arsenic in soil.

It has also been reported that P-deficient plants could exude LMWOAs and result in enhanced availability (Hoffland, 1992; Neumann and Römheld, 1999; Kirk et al., 1999). This response is thought to change soil $\mathrm{pH}$, displace $\mathrm{P}$ from sorption sites, chelate metal cations that could immobilize $\mathrm{P}$ or to form soluble metal-chelate complexes with $\mathrm{P}$ (Kirk et al., 1999). Arsenic and $\mathrm{P}$ belong to the same chemical group and have comparable dissociation constants for their acids and solubility products for their salts, and represent similar geochemical behavior in soil (Adriano, 2001). So, it is reasonable to predict that LMWOAs exudation could also play a role in the mobilization of As in soil. However, there is still no direct evidence to these speculations.

Several LMWOAs have been identified as exudation products in soil rhizosphere processes (Lundström, 1994; Jones and Darrah, 1994), of which citrate, malate and oxalate are the most important compounds. Therefore, in this study we investigate the influences of these three organic anions on the solubility of arsenite and arsenate in a contaminated soil. Effects of the LMWOAs concentration and $\mathrm{pH}$ were investigated. The relationship between arsenic mobility and the co-released $\mathrm{Mn}, \mathrm{Al}$ and $\mathrm{Fe}$ was also investigated in order to explain the mechanism. Such knowledge of the fate of arsenic in the soil is particularly valuable for risk assessment of arsenic in environment. 


\section{Materials and Methods}

\subsection{SOIL}

The soil heavily contaminated with arsenic was collected in Xingren county, Guizhou province in China. The sampling site was in farmland and close to a thallium ore deposit. The soil sample was air-dried and ground to pass through a 2-mm sieve, homogenized and analyzed. Soil $\mathrm{pH}$ was measured in aqueous slurry of 1:1 soil and water mixture. Organic matter in soil was determined by the Walkley-Black method (Nelson and Sommer, 1982). Cation exchange capacity (CEC) of the soil was determined by the method described by Rhoades (1982). Selected properties of the soil sample and metal concentrations are presented in Table I.

\subsection{EXTRACTION}

Triplicate $2.00 \mathrm{~g}$ of the soil sample were weighed into $50 \mathrm{ml}$ polypropylene tubes and $20 \mathrm{ml}$ of extraction solution was added. The samples were then shaken at $20^{\circ} \mathrm{C}$ for 16 hours. $\mathrm{pH}$ of the suspension was kept at $\mathrm{pH} 5.5$ adjusted with $0.1 \mathrm{M} \mathrm{HCl}$ or $\mathrm{NaOH}$ with less than $2 \%$ of the volume changed. The extracted samples were then centrifuged and filtered through a filter of $0.45-\mathrm{mm}$ pore size and diluted before analysis.

TABLE I

Selected physical and chemical characteristics of the soil

\begin{tabular}{lc}
\hline Property & \\
\hline Particle size (\%) & \\
$>200 \mu \mathrm{m}$ & 55.66 \\
$20-200 \mu \mathrm{m}$ & 39.36 \\
$2-20 \mu \mathrm{m}$ & 4.91 \\
$<2 \mu \mathrm{m}$ & 0.07 \\
$\mathrm{pH}\left(1: 1\right.$ in $\left.\mathrm{H}_{2} \mathrm{O}\right)$ & 6.37 \\
$\mathrm{CEC}(\mathrm{c} \mathrm{mol} / \mathrm{kg})$ & 15.2 \\
$\mathrm{OM}(\%)$ & 6.73 \\
$\mathrm{As}, \mathrm{mg} \mathrm{kg}^{-1}$ & $302.2 \pm 16.1$ \\
$\mathrm{Fe}, \mathrm{g} \mathrm{kg}^{-1}$ & $52.2 \pm 2.1$ \\
$\mathrm{Al}, \mathrm{g} \mathrm{kg}^{-1}$ & $25.9 \pm 1.2$ \\
$\mathrm{Mn}, \mathrm{g} \mathrm{kg}^{-1}$ & $1.1 \pm 0.1$ \\
\hline
\end{tabular}




\subsection{Determination of As}

Arsenic concentrations were determined by hydride generation atomic fluorescence spectrometry (HG-AFS, AFS-230 model atomic fluorescence spectrophotometer, Beijing Haiguang Instrumental Company, Beijing, China). An automatic intermittent hydride generation device was used to generate the arsenic hydride. Argon gas was used as the carrier gas for the transposition of arsenic hydride from the hydride generator to the atomizer. Fluorescence measurements for samples were interpolated using the calibration line with As(III) standards. A calibration plot was obtained from 0 to $30 \mu \mathrm{g} \mathrm{L}^{-1}$ As measured in the same conditions as those for the samples. This solution was continuously feed at a carrier flow of $6 \mathrm{ml} \mathrm{min}{ }^{-1}$ and mixed with a flow of the reducing solution $\left(\mathrm{NaBH}_{4} 3.0 \% \mathrm{w} \mathrm{v}^{-1}\right.$ in $\mathrm{NaOH}$ $\left.0.5 \mathrm{w} \mathrm{v}^{-1}\right)$. The $\mathrm{AsH}_{3}$ generated was transferred to fluorescence spectrometry by

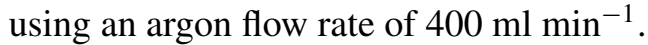

Inorganic arsenic species were selectively determined by exploiting the generation of $\mathrm{As}(\mathrm{V})$ from $\mathrm{As}(\mathrm{III})$ at low acidic medium while arsenate does not produce any signal. Total arsenic was determined by hydride generation under strong acidic condition after the $\mathrm{As}(\mathrm{V})$ completely reduced to the trivalent state with $10 \mathrm{~g} \mathrm{~L}^{-1}$ thiourea according to the method proposed by Han and Wang (1985). Then $\mathrm{As}(\mathrm{V})$ was calculated from the difference between $\mathrm{As}(\mathrm{III})$ and the total arsenic concentration.

Arsenic stock solutions were obtained from National Research Center for Certified Reference Materials, Beijing, China. All the reagents used were of analytical reagent grade or better.

All the data obtained by three replicate analyses. Statistical analysis was performed by use of the Office XP-Excel and Origin 6.0.

\section{Results and Discussion}

\subsection{DETERMINATION OF ARSENIC SPECIATION}

Inorganic As is the predominant form of arsenic in soil (Cullen and Reimer, 1989; Garcia-Manyes et al., 2002). We first analyzed the arsenic speciation in the soil extracts by HPLC-HG-AAS, The chromatograms displaying a multispecies solution containing $10 \mu \mathrm{g} \mathrm{L}^{-1}$ of As(III), As(V), monomethylarsonate (MMA), dimethylarsinate (DMA) and the soil extract by $5 \mathrm{mM}$ citrate are given in Figure 1. No MMA and DMA were detected in the soil extract. Therefore, in this work only inorganic species were further investigated.

In order to make sure that As(III) could be selectively determined without interference from arsenic (V) and As(V) could be totally reduced to As(III) by thiourea for the total As determination, a series of solution with $10 \mu \mathrm{g} \mathrm{L}^{-1}$ of As(III) and different concentrations of $\mathrm{As}(\mathrm{V})$ were analyzed. The results are listed in Table II. 


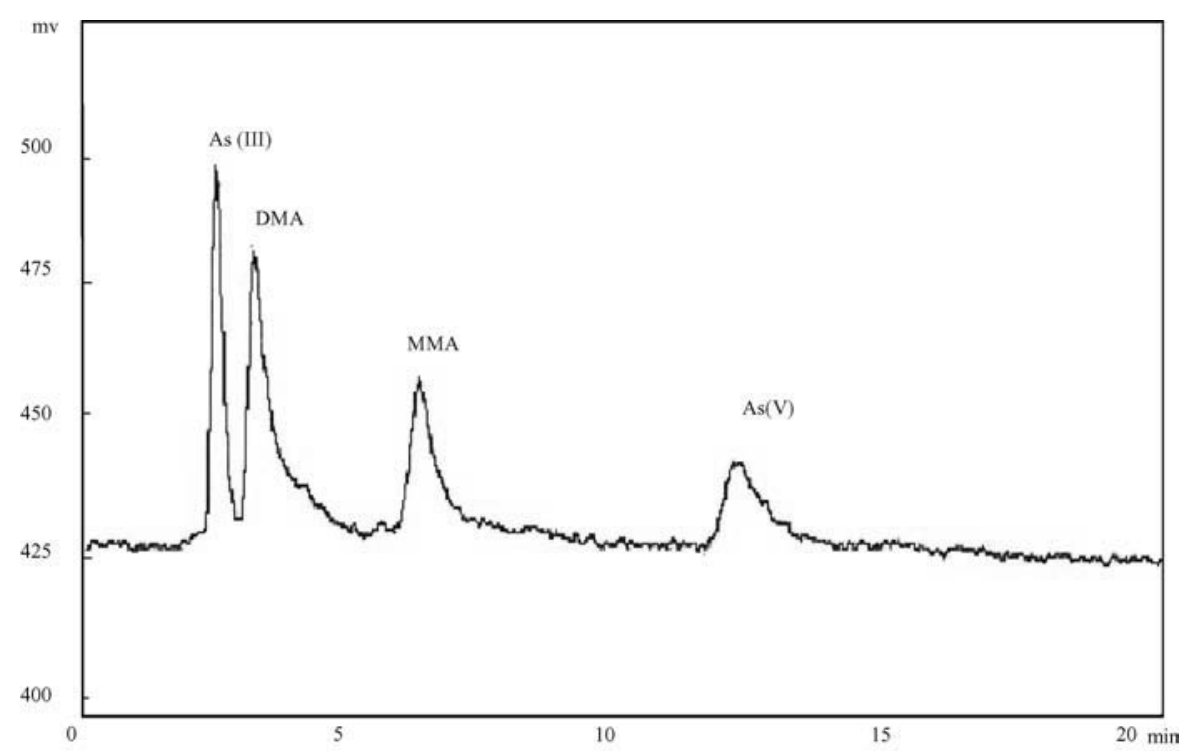

(A)

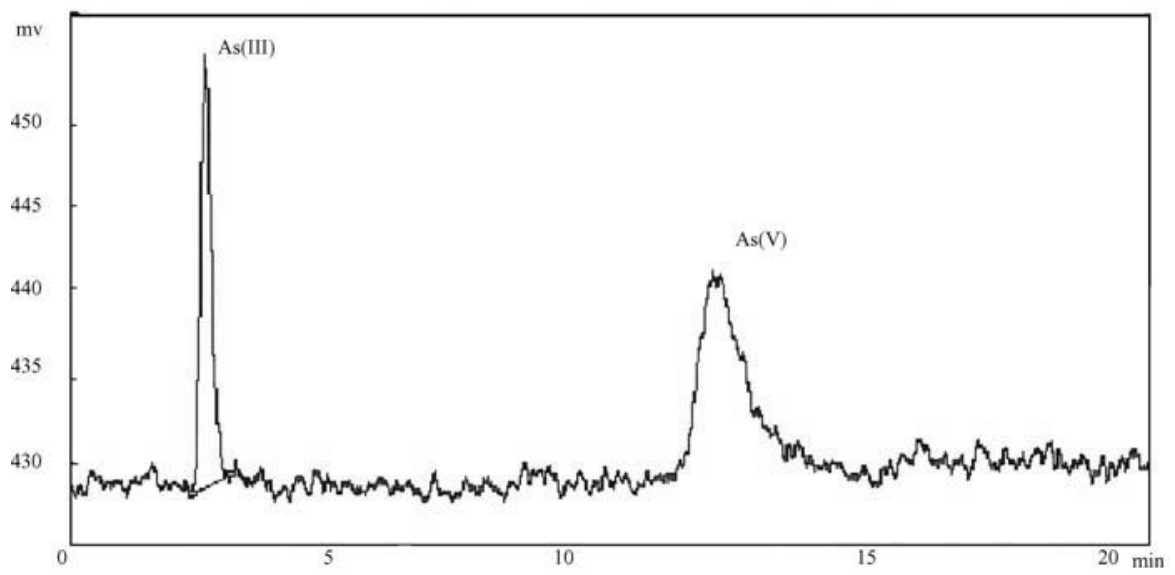

(B)

Figure 1. Chromatograms of arsenic speciation obtained from the HPLC-HG-AAS analyses; (A) standard solution (10 $\mu \mathrm{g} \mathrm{g}^{-1} \mathrm{As}(\mathrm{III}), \mathrm{As}(\mathrm{V})$, MMA and DMA); (B) soil solution extracted by $5 \mathrm{mM}$ citric acid at $\mathrm{pH}$ 5.5).

We can see that there is no interference from As(III) for the determination of As(III) and the $\mathrm{As}(\mathrm{V})$ could be quantitatively reduced to As(III) with thiourea.

Quality assurance was carried out by the determination of total arsenic in soil certified reference materials (GBW 07408 and GBW 08302 purchased from the National Research Center for Certified Reference Materials, Beijing, China). Seven replicated analyses were made for each sample. The results obtained were 
TABLE II

\begin{tabular}{|c|c|c|c|}
\hline \multicolumn{2}{|c|}{ Added } & \multicolumn{2}{|c|}{ Detected } \\
\hline As (III) & As (V) & As (III) & As $(V)$ \\
\hline 10.0 & 0 & 10.1 & 0 \\
\hline 10.0 & 4.0 & 10.0 & 4.1 \\
\hline 10.0 & 8.0 & 10.1 & 7.8 \\
\hline 10.0 & 12.0 & 10.1 & 11.9 \\
\hline 10.0 & 16.0 & 10.1 & 16.3 \\
\hline 10.0 & 20.0 & 10.0 & 20.2 \\
\hline
\end{tabular}

$12.1 \pm 1.0 \mu \mathrm{g} \mathrm{g}^{-1}$ and $4.0 \pm 0.3 \mu \mathrm{g} \mathrm{g}^{-1}$ for GBW 07408 and GBW 08302 , respectively. The certified values are $12.7 \pm 1.7 \mu \mathrm{g} \mathrm{g}^{-1}$ and $3.8 \pm 0.4 \mu \mathrm{g} \mathrm{g}^{-1}$ for GBW 07408 and GBW 08302, respectively. Good agreements were achieved between the data obtained by the present method and the certified values.

\subsection{EFFECT OF THE ORGANIC ACIDS UPON THE RELEASE OF ARSENITE AND ARSENATE}

It has been reported that concentrations of organic acids in soil solution are in the range of $1 \times 10^{-3}$ to $4 \times 10^{-4} \mathrm{M}$ (Stevenson and Ardakani 1972; Stevenson, 1994). Higher concentrations $\left(>10^{-3} \mathrm{M}\right)$ of LMWOAs would be expected to be produced in localized zones where biological activity is intense, such as the rhizosphere (Rovira, 1969; Stevenson, 1991) and near decomposing plant residues (Bruckert, 1970; Bruckert and Kacquin, 1969). Therefore, dissolution of As in the contaminated soil by citrate, malate and oxalate in the concentration range from 0 to $10 \mathrm{mM}$ was investigated. The release curves for total As, As(III) and As(V) in different concentration of citrate, malate and oxalate are presented in Figures 2A-C. The total concentration of As in the soil is $302.2 \mathrm{mg} \mathrm{kg}^{-1}$ and the dissolved As by water is about $0.5 \mu \mathrm{g} \mathrm{g}^{-1}$, representing only $0.17 \%$ of the total As in the soil, which suggests that a relative low soluble As representing in the contaminated soil in mining areas and there should be no threat upon the groundwater quality. Similar results were also reported in the As contaminated soils in southwestern England by Abedin et al. (2002). However, in the presence of organic anions, enhanced As solubility was observed. Linear relationships $(p<0.01)$ exit between the dissolved As and the concentrations of LMWOAs in the extractants and the $R^{2}$ values are from 0.9695 to 0.9982 , as shown in Figures $2 \mathrm{~A}-\mathrm{C}$. We should pay more attention to such phenomenon because the LMWOAs exudation always happens in the rhizosphere process. The observation of LMWOAs enhancing the arsenic solubility 

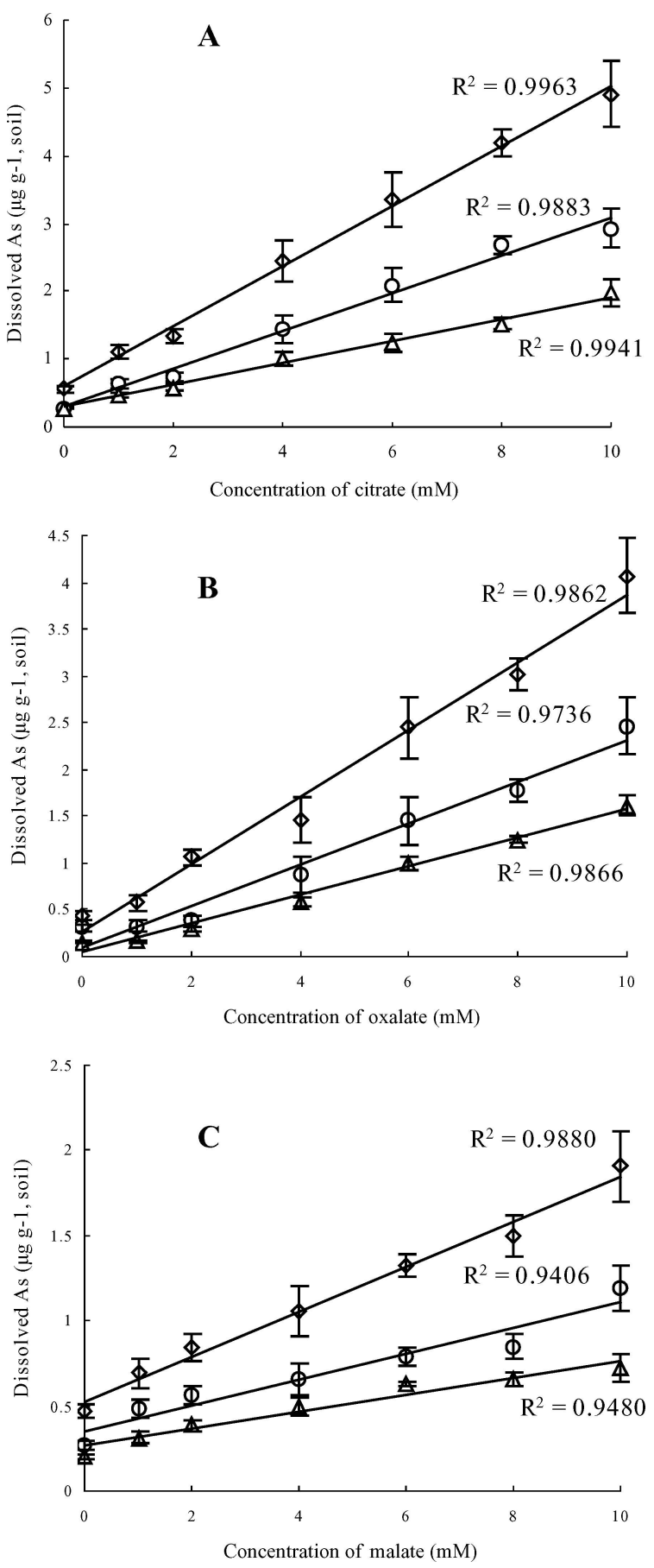

Figure 2. Dissolve of As with different concentrations of LOMWAs at pH $5.5 \diamond$ : Total As, ०: As(V) and $\Delta: \operatorname{As}(\mathrm{III})$. 
TABLE III

Concentration of co-released $\mathrm{Fe}, \mathrm{Mn}$ and $\mathrm{Al}$ by different concentration of low molecular weight organic acids $\left(\mu \mathrm{g} \mathrm{g}^{-1}\right)$

\begin{tabular}{|c|c|c|c|c|c|c|c|c|c|}
\hline \multirow{2}{*}{$\begin{array}{l}\text { Conc. of LMWOA } \\
(\mathrm{mM})\end{array}$} & \multicolumn{3}{|c|}{ Citrate } & \multicolumn{3}{|c|}{ Oxalate } & \multicolumn{3}{|c|}{ Malate } \\
\hline & $\mathrm{Fe}$ & $\mathrm{Mn}$ & $\mathrm{Al}$ & $\mathrm{Fe}$ & $\mathrm{Mn}$ & $\mathrm{Al}$ & $\mathrm{Fe}$ & $\mathrm{Mn}$ & $\mathrm{Al}$ \\
\hline 0 & 19.4 & 0.44 & 14.2 & 18.6 & 0.50 & 7.9 & 4.7 & 0.38 & 6.7 \\
\hline 1 & 35.9 & 1.2 & 34.8 & 14.9 & 0.73 & 11.8 & 5.7 & 0.46 & 6.3 \\
\hline 2 & 63.4 & 3.9 & 27.1 & 40.5 & 2.9 & 61.3 & 6.2 & 0.77 & 6.9 \\
\hline 4 & 92.2 & 22.1 & 77.4 & 75.1 & 3.0 & 53.0 & 8.9 & 1.7 & 10.2 \\
\hline 6 & 114.6 & 35.7 & 78.6 & 105 & 3.4 & 62.3 & 10.9 & 2.7 & 9.4 \\
\hline 8 & 189.8 & 49.4 & 122.0 & 134.2 & 4.2 & 67.5 & 46.7 & 24.1 & 38.1 \\
\hline 10 & 347.7 & 101.6 & 207.4 & 203.2 & 10.0 & 252.0 & 75.4 & 37.2 & 44.3 \\
\hline
\end{tabular}

indicates that such process will consequently increase the mobility of arsenic in soil.

It was reported that As adsorption in soils is most controlled by surface complexation reactions with the oxides/hydroxides of $\mathrm{Al}, \mathrm{Mn}$ and especially Fe (Inskeep et al., 2002). Therefore in this study the co-released Fe, Mn and Al were investigated. The results are listed in Table III. Increasing concentrations of $\mathrm{Fe}, \mathrm{Al}$ and Mn were observed with the increase of the LMWOAs concentration. Statistical analysis shows that As released is significantly correlated with the co-released contents of $\mathrm{Fe}, \mathrm{Al}$ and $\mathrm{Mn}$ (Table IV), the correlation coefficient ( $r$ ) ranges from 0.7794 to 0.9920 . Citrate, malate and oxalate all have a high affinity for trivalent metals such as $\mathrm{Al}^{3+}$ and $\mathrm{Fe}^{3+}$ and bivalent $\mathrm{Mn}^{2+}$ (Jones, 1998), as shown in Table V. The effect of LMWOAs upon the increasing solubility of arsenic could have contributed to the dissolution of $\mathrm{Fe}, \mathrm{Mn}$ and $\mathrm{Al}$ by LMWOAs. The dissolved As by different LMWOAs is in the order: citrate $>$ oxalate $>$ malate, which is consistent with the order of the stability constants of Fe-, Al- and Mn-organic ligand complexes.

TABLE IV

Correlation coefficient for As released in soil with the co-released $\mathrm{Fe}, \mathrm{Mn}$ and $\mathrm{Al}\left(R^{2}\right)$

\begin{tabular}{llll}
\hline Organic acid & $\mathrm{Fe}$ & $\mathrm{Mn}$ & $\mathrm{Al}$ \\
\hline Citrate & $0.9205^{*}$ & $0.9342^{*}$ & $0.9588^{*}$ \\
Oxalate & $0.9920^{*}$ & $0.8305^{* *}$ & $0.9001^{*}$ \\
malate & $0.8985^{*}$ & $0.7794^{* *}$ & $0.8166^{* *}$ \\
\hline
\end{tabular}

*Significant at 0.01 probability level.

** Significant at 0.05 probability level. 
TABLE V

Stability constants of organic acid-metal complexes (Martell and Smith, 1976-1989)

\begin{tabular}{lrll}
\hline Metal & Citrate & Oxalate & Malate \\
\hline $\mathrm{Fe}^{3+}$ & 11.50 & 7.74 & 7.1 \\
$\mathrm{Al}^{3+}$ & 7.87 & 6.1 & 6.0 \\
$\mathrm{Mn}^{2+}$ & 2.93 & 1.38 & 1.39 \\
\hline
\end{tabular}

The physiological and toxicological effects of arsenic depend on its chemical form (Cullen and Reimer, 1989). As(III) is much more toxic, soluble and mobile than $\mathrm{As}(\mathrm{V})$. We can see from Figures $2 \mathrm{~A}-\mathrm{C}$ that no matter what kind of LMWOAs was present, the extracted As(V) was higher than that of As(III). The ratio of As(V) to As(III) extracted was almost constant. Without organic acid, the ratio was 1.32, and in the presence of $5 \mathrm{mM}$ of citric, oxalic and malic acid, the ratio is $1.45,1.45$ and 1.35 , respectively. The results give us a hint that there is no preferential release of arsenic species in the presence of organic anions.

\section{3. pH DEPENDENCE OF THE RELEASE ARSENITE AND ARSENATE IN THE PRESENCE OF LMWOAS}

It is generally known that rhizosphere $\mathrm{pH}$ may considerably differ from that in the bulk soil. Depending on plant and soil factors $\mathrm{pH}$ differences can be up to two units. Therefore, the effect of solution $\mathrm{pH}$ on the release of arsenite and arsenate in the presence of LMWOAs was studied and the results are shown in Figure 3A-C. The $\mathrm{pH}$ of the solution appeared to have weak effect on the amount of As(III) and As(V) released. Previous studies (Manning and Goldbery, 1997; Smith, 1999) using soil and pure $\mathrm{Fe}$ hydroxides to investigate the $\mathrm{pH}$-dependent arsenic desorption reveled that $\mathrm{As}(\mathrm{V})$ solubility increased upon the increasing $\mathrm{pH}$ in range from 3 to 8, whereas As(III) tended to follow the opposite pattern. Masschelyn et al. (1991) also observed that soluble As concentration was three times larger at $\mathrm{pH} 8$ than at $\mathrm{pH} 5$, and the authors contributed the results to the decrease of positive surface charge at high $\mathrm{pH}$. However, in this research we found that both the total dissolved As and $\mathrm{As}(\mathrm{V})$ decreased slightly with the increasing $\mathrm{pH}$. The released As(III) increased slightly in the presence of malate. In the presence of citrate or oxalate, the released As(III) slightly decreased first and then increased when the $\mathrm{pH}$ was higher than 6 . The differences of this work from previous results of $\mathrm{pH}$-dependent As desorption could be attributed to the contribution of LMWOAs. LMWOAs have a strong affinity with soil particles. But as the $\mathrm{pH}$ of the suspension increases, the soil surface becomes more negative. A greater repulsive interaction between the organic anions and the mineral surface tends to lower the affinity of LMWOAs for soil. In this situation, LMWOAs complex less Fe, Al and Mn, leading to less 

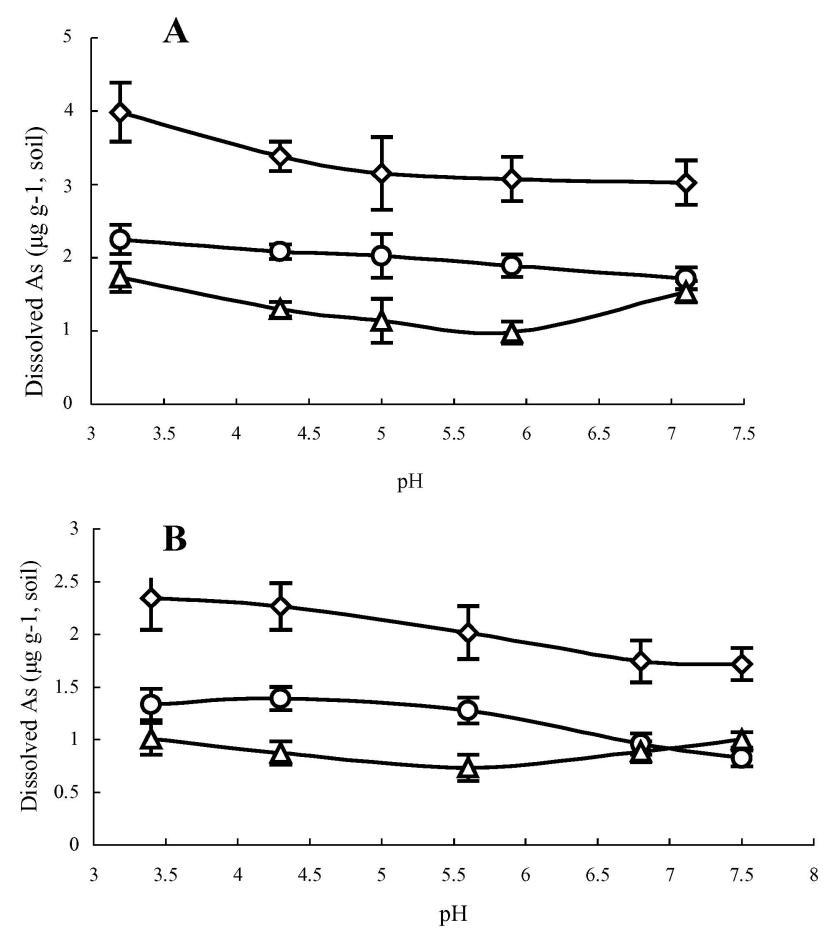

C

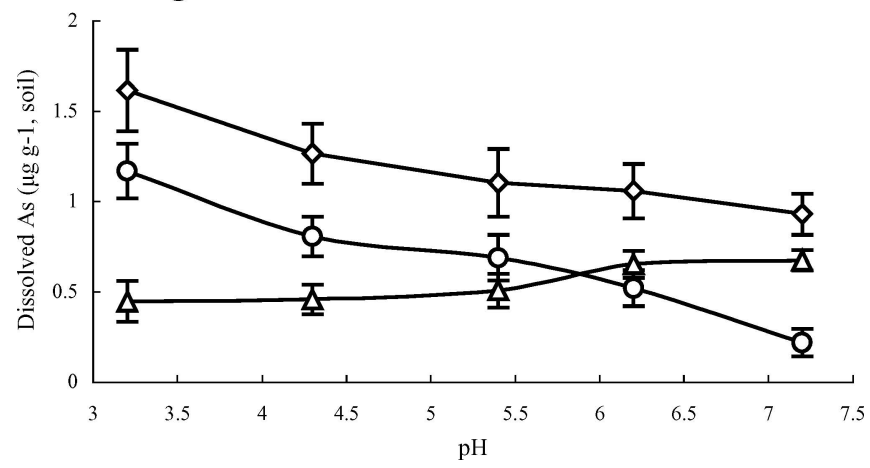

Figure 3. Dissolve of As in the presence of $5 \mathrm{mM}$ LOMWAs at different $\mathrm{pH} . \diamond$ : Total As, $\bigcirc$ : As(V) and $\Delta: \mathrm{As}(\mathrm{III})$. A: citrate, B: oxalate, C: malate.

arsenic being released. The presence of LMWOAs made the desorption mechanism of arsenic more complicated.

\section{Conclusion}

The results of this study indicate that in the presence of citrate, malate and oxalate, the solubility of arsenic is significantly increased. Linear relationships exist 
between the dissolved As(III) and As(V) and the concentrations of LMWOAs in the extractant. However, the $\mathrm{pH}$ of the solution has a weak effect on the amount of $\mathrm{As}(\mathrm{III})$ and $\mathrm{As}(\mathrm{V})$ released. As(III) and $\mathrm{As}(\mathrm{V})$ released are significantly correlated with the co-released concentrations of $\mathrm{Fe}, \mathrm{Al}$ and $\mathrm{Mn}$ in the solution. The mechanism could be the dissolution of $\mathrm{Fe}, \mathrm{Mn}$ and $\mathrm{Al}$ from soil by LMWOAs, increasing released arsenic. There is no preferential release between $\mathrm{As}(\mathrm{III})$ and $\mathrm{As}(\mathrm{V})$ in the presence of LMWOAs. LMWOAs always exist in soil, their effect upon the mobility of arsenic should be considered for the environmental risk assessment.

\section{Acknowledgements}

This work was funded by National Natural Science Foundation of China (No. 20377049) and Chinese Academy of Sciences (Grant No. KZCX3-SW-431).

\section{References}

Abedin, M. J., Feldmann, J. and Meharg, A. A.: 2002 'Uptake kinetics of arsenic species in rice plant', Plant Physiol. 128, 1120-1128.

Adriano, D. C.: 2001, Trace Elements in the Terrestrial Environment, Springer, New York.

Barrow, N. J.: 1974, 'On the displacement of adsorbed anions from soil: 2. Displacement of phosphate by arsenate', Soil Sci. 117, 29-33.

Berg, M., Tran, H. C., Nguyen, T. C., Pham, H. V., Schertenleib, R. and Giger, W.: 2001, 'Arsenic contamination of groundwater and drinking water in Vietnam: A human health threat', Environ. Sci. Technol. 35, 2621-2626.

Brandstetter, A., Lombi, E. and Wenzel, W. W.: 2000, 'Arsenic-contaminated soils: I. Risk assessment', in D. L. Wise, D. J. Tarantolo, E. J. Cichon, H. I. Inyan and U. Stottmeister (eds), Remediation Engineering of Contaminated Soils, Marcel Dekker, New York, pp. 715-737.

Burckert, S.: 1970, 'Influence des composes organiqurs solubles sur la pedogenese en milieu acide', Ann. Agron. 21,421-452.

Burckert, S. and Jacquin, F.: 1969, 'Inreaction entre lamobile de plusieurs acides organiques et de divercations dans un sol a mull et dans un sol a mor', Soil Biol. Biochem. 1, 275-294.

Christen, K.: 2000, 'World's most stringent arsenic standard proposed', Environ. Sci. Technol. 34, 291A-292A.

Cieslinski, G., Rees, K. C. J. V., Szmigielska, A. M., Krishnamurti, G. S. R. and Huang, P. M.: 1998, 'Low-molecular-weight-organic acids in rhizosphere soils of durum wheat and their effect on cadmium bioaccumulation plant and soil', Plant Soil. 203, 109-117.

Cullen, W. R. and Reimer, K. J.: 1989, 'Arsenic speciation in the environment', Chem. Rev. 89, 713-764.

Dinkelaker, B., Römheld, V. and Marschner, H.: 1989, 'Citric acid excretion and precipitation of calcium citrate in the rhizosphere of white lupin (Lupinus alubs L.)', Plant Cell and Environment. 12, 285-292.

European Union.: 1998, Council Directive 98/83/EC on the Quality of Water Intended for Human Consumption.

Garcia-Manyes, S., Jimenez, G., Padro, A., Rubio, R. and Rauret, G.: 2002, 'Arsenic speciation in contaminated soils', Talanta. 58, 97-109. 
Han, H. B. and Wang, W. D.: 1985, 'Determination of As(III), As(V), Te(III), Te(V), Se(IV) and $\mathrm{Se}(\mathrm{VI})$ in river water and waste water by hydride generation atomic fluorescence spectrometry', Environ. Chem. 4, 52-57 (in Chinese).

Hoffland, E.: 1992, 'Quantitative evaluation of the role of organic acid exudation in the mobilization of rock phosphate by rape', Plant Soil. 140, 279-289.

Inskeep, W. P., McDermott, T. R. and Fendorf, S.: 2002, 'Arsenic (V)/(III) cycling in soil and natural waters: Chemical and microbiological processes', in W. T. Frankenberger (ed), Environmental Chemistry of Arsenic, Marcel Dekker, New York, pp. 183-215.

Jones, D. L. and Darrah, P. R.: 1994, 'Role of root derived organic acids in the mobilization of nutrients from the rhizosphere', Plant Soil. 166, 247-257.

Kirk, G. J. D., Santos, E. E. and Findenegg, G. R.: 1999, 'Phosphate solubilisation by organic anion excretion from rice (Oryza sativa L.) growing in aerobic soil', Plant Soil. 211, 11-18.

Kochian, L. V.: 1995, 'Cellular mechanisms of aluminum toxicity and resistance in plants', Ann. Rev. Plant Physiol. Plant Mol. Biol. 46, 237-260.

Livesey, N. T. and Huang, P. M.: 1981, 'Adsorption of arsenate by soils and its relation to selected chemical properties and anions', Soil Sci. 134, 88-94.

Lundström, U. S.: 1994, 'Significance of organic acids for weathering and the podzolizationprocess', Environ. Intern. 20, 21-30.

Mandal, B. K. and Suzuki, K. T.: 2002, 'Arsenic round the world: A review', Talanta. 58, 201-235.

Manning, B. A. and Goldberg, S.: 1997, 'Arsenic (III) and arsenic (V) adsorption on three California soils', Soil Sci. 162, 886-895.

Marschner, H.: 1986, Mineral Nutrition of Higher Plants, Academic Press, London.

Martell, A. E. and Smith, R. M.: 1989, Critical Stability Constants, Vol. 3: Other Organic Lignads, Plenum Press, New York and London.

Masscheleyn, P. H., Delaune, R. D. and Patrick, J. W. H.: 1991, 'Effect of redox potential and pH on arsenic speciation and solubility in a contaminated soil', Environ. Sci. Technol. 25, 1414-1419.

Meharg, A. A., Naylor, J. and Macnair, M. R.: 1994, 'Phosphorus nutrition of arsenate tolerant and nontolerant phenotypes of velvet grass', J. Environ. Qual. 23, 234-238.

Nelson, D. W. and Sommers, L. E.: 1982, 'Total carbon, organic carbon and organic matter', in A. L. Page, R. H. Miller and D. R. Keeney (eds), Methods of Soil Analysis, Part 2, American Society of Agronomy Madison, WI, USA, pp. 539-579.

Neumann, G. and Römheld, V.: 1999, 'Root excretion of carboxylic acids and protons in phosphorousdeficient plants', 211, 121-130.

Rhoades, J. D.:1982, 'Cation-exchange capacity', in A. L. Page, R. H. Miller and D. R. Keeney (eds), Methods of Soil Analysis, Part 2, American Society of Agronomy Madison, WI, USA, pp. 149-158.

Rovira, A. D.: 1969, 'Plant root exudates', Bot. Rev. 35, 35-37.

Smith, E., Naidu, R. and Alston, A. M.: 1998, 'Chemistry of arsenic in soils: I. Sorption of arsenate and arsenite by four Australian soils', J. Environ. Qual. 28, 1719-1726.

Stevenson, F. J. and Ardakani, M. S.: 1972, 'Organic matter interactions involving micronutrients in soils', in J. J. Mortvedt, P. M. Giordano and W. L. Lindsay (eds), Micronutrients in Agriculture, Soil Sci. Soc. Am., Madison, WI, USA, pp. 79-114.

Stevenson, F. J.: 1994, Humus Chemistry. Genesis, Composition, Reactions. 2nd ed., John Wiley \& Sons, New York.

Stevenson, F. J.: 1991, 'Organic matter-micronutrient reactions in soil', in J. J. Mortvedt, F. R. Cox, L. M. Shuman and R. M. Welch (eds), Micronutrients in Agriculture, 2nd ed., Soil Sci. Soc. Am., Madison, WI, USA, pp. 145-186.

Ström, L., Owen, A. G., Godbold, D. L. and Jones, D. L.: 2002, 'Organic acid behavior in a calcareous soil: Sorption reactions and biodegradation rates', Soil Biol. Biochem. 33, 2125-2133. 